Cahiers $d u$ MONDE RUSSE

\section{Cahiers du monde russe}

Russie - Empire russe - Union soviétique et États indépendants

$43 / 1 \mid 2002$

Varia

\title{
Technical muses : Piano builders in Russia,
}

1810-1881.

Anne SWARTZ

\section{OpenEdition}

\section{Journals}

Édition électronique

URL : https://journals.openedition.org/monderusse/8485

DOI : 10.4000/monderusse.8485

ISSN : $1777-5388$

Éditeur

Éditions de l'EHESS

Édition imprimée

Date de publication : 1 janvier 2002

Pagination : 119-138

ISBN : 2-7132-1773-3

ISSN : $1252-6576$

Référence électronique

Anne SWARTZ, "Technical muses : Piano builders in Russia, 1810-1881. », Cahiers du monde russe [En ligne], 43/1 | 2002, mis en ligne le 01 janvier 2007, consulté le 02 septembre 2022. URL : http:// journals.openedition.org/monderusse/8485; DOI : https://doi.org/10.4000/monderusse.8485 
chercher : repérer : avancer

Cet article est disponible en ligne à l'adresse :

http://www.cairn.info/article.php?ID REVUE=CMR\&ID NUMPUBLIE=CMR 431\&ID ARTICLE=CMR 4310103

Technical muses: Piano builders in Russia, 1810-1881

par Anne SWARTZ

| Editions de l'EHESS | Cahiers du monde russe

2002/1 - Vol 43

ISSN 1252-6576 | ISBN 2713217733 | pages 103 à 118

Pour citer cet article :

—SWARTZ A., Technical muses: Piano builders in Russia, 1810-1881, Cahiers du monde russe 2002/1, Vol 43, p. 103118.

Distribution électronique Cairn pour les Editions de l'EHESS.

(C) Editions de l'EHESS. Tous droits réservés pour tous pays.

La reproduction ou représentation de cet article, notamment par photocopie, n'est autorisée que dans les limites des conditions générales d'utilisation du site ou, le cas échéant, des conditions générales de la licence souscrite par votre établissement. Toute autre reproduction ou représentation, en tout ou partie, sous quelque forme et de quelque manière que ce soit, est interdite sauf accord préalable et écrit de l'éditeur, en dehors des cas prévus par la législation en vigueur en France. Il est précisé que son stockage dans une base de données est également interdit. 


\section{TECHNOLOGICAL MUSES: PIANO BUILDERS IN RUSSIA, 1810-1881}

In the summer of 1842 the romantic idol Franz Liszt (1811-1886) presented one of his earliest solo recitals in Russia. The official organ, the Journal de SaintPétersbourg, 18/30 August 1842, reported that Liszt exploited the extreme limits of the keyboard and endorsed a Russian-manufactured piano. The article attests to the master's tremendous popularity in the capital and to the instrument's social cachet:

"M. Liszt. Il n'est que midi. Où vont donc ces brillants équipages qui, de toutes parts, se hâtent à cette heure inaccoutumée ? À quelque fête solennelle, sans doute? Point du tout. Mais alors quelle peut être la cause de tant d'empressement? La cause? Une toute petite affiche, bien laconique, bien simple. Voici ce que c'est. Un virtuose annonce que tel jour, à deux heures, dans la salle de l'Assemblée de la Noblesse, il exécutera, sans le concours d'un orchestre, sans le prestige d'un concert dans toutes les règles, cinq ou six morceaux sur son instrument. À cette nouvelle, toute la ville accourt; voyez; une foule immense se rassemble; on se presse, on se coudoie, on entre. Il n'en coûtait que quinze roubles pour être admis, et pourtant la recette se monte à plus de cinquante mille roubles!"1

I should like to thank the National Endowment for the Humanities (Special Opportunity for Archival Research), the Kennan Institute for Advanced Russian Studies (Short-term grant), the International Research and Exchanges Board (Grant for Short-term Independent Research), and the City University of New York Research Award program for supporting research and travel for the completion of this project. I also extend thanks to Annie Hemmingway, Faina Davidovna Bartnovskaia, and the staff of the Russian National Library. Transliterations of the Cyrillic alphabet are based on the Library of Congress system. I am using modern Russian spelling. The names of some nineteenth-century Russian composers have been spelled in the western European manner. Dates are given according to the Julian, or Russian calendar, except where the author or editor employs Julian and Gregorian dates. In those instances both dates are provided as in the original source.

1. Journal de Saint-Pétersbourg (18/30 août 1842): 1929. "Liszt. It is only noon. Where are those brilliant carriages traveling from every direction going with such speed at this unusual hour? Probably to some celebration? Not at all. But what is the reason for such haste? A very small notice, 
Pianos were found in the homes of the gentry and raznochintsy (intellectuals not belonging to the gentry in nineteenth-century Russia). Solo piano recitals that featured one performer playing his or her own works, as well as works of contemporary composers, began after 1840 in St. Petersburg with Liszt. Audiences began to draw a distinction between the concerts of local amateur societies and those that exploited the skills of the professional musician. The amateur societies essentially served an educational function in Russian society in the 1820 s and $1830 \mathrm{~s}$. In particular, the wealthier merchant classes tended to imitate the gentry. Membership in the amateur musical societies reinforced the social and cultural ties between the gentry and raznochintsy. The importance of musical society and professional concerts directly affected the piano manufacturing sector. By 1840 the smaller pianino, or upright piano, was a staple in most households in Moscow and St. Petersburg. Manufacturers marketed the piano as a symbol of upward mobility. Merchants, factory owners, and gentry with annual incomes of 1,200 to 4,000 rubles owned one or two of the smaller upright pianos. Pianists and private music tutors were fashionable because they helped the younger generations of Russian aristocracy acquire the trappings of western culture.

Moreover, among the ranks of the gentry, the emblems of wealth were often embedded in the ability to sing and play the pianoforte. Contemporary Russian writers spoke of these musical "accomplishments" in order to reinforce their characters" refinement and gentility. The theme of the pianoforte occurs throughout Turgenev's novel, Dvorianskoe gnezdo (1848). It serves as an appropriate accompaniment to the nuances of romantic love. For example, when Vladimir Nikolaevich Panshin, a minor official in St. Petersburg's Ministry of Internal Affairs, is assigned to the provincial town of $\mathrm{O}$..., he shows himself at ease in the drawing room of an estate by exhibiting his expertise at the piano. Varvara Pavlovna, the daughter of a retired St. Petersburg majorgeneral and the estranged wife of the slavophile Fedor Lavretskii, is an accomplished pianist. Turgenev employs the imagery of the piano to illustrate the artificial social world represented by Panshin and Varvara Pavlovna:

"Varvara Pavlovna sat down at the piano. Panshin stood beside her. They sang the duet in a low voice, with Varvara Pavlovna correcting him a number of times, and then they sang it aloud and twice repeated. 'Mira la bianca Iu...u...una.' Varvara Pavlovna's voice had lost its freshness, but she used it very cleverly. Panshin was diffident at first and slightly out of tune, then he came into his own and, if he did not sing irreproachably, he at least made his shoulders quiver, swayed his whole body and raised his hand from time to time like a real singer. Varvara Pavlovna played two or three pieces by Thalberg and coquettishly 'spoke' a French ariette."'2

brief and simple. Here's what it says. A virtuoso announces that on a certain day, at two o'clock, in the Hall of the Assembly of the Nobles, he will play five or six pieces on his piano, without the accompaniment of the orchestra, without the usual prestige of a regular concert. Upon hearing this news, the entire city rushed. Look! An immense crowd gathers, people squeeze together, elbow each other and enter. It costs only 15 rubles to get in and yet the receipts total more than 50,000 rubles."

2. Ivan Turgenev, Home of the gentry, translated by Richard Freeborn (New York: Viking, 1970):169-170. 
Visiting European artists Sigismond Thalberg (1812-1871), Alexander Dreyschock (1818-1869), Clara Wieck Schumann (1819-1896), and Marie-Félicité-Denise [Madame Camille] Pleyel, née Moke (1811-1875), in addition to Liszt, performed on Russian-manufactured pianos. Russian manufacturers aggressively marketed the concert roial', or grand piano. They engaged visiting artists in lively marketing campaigns. Liszt, for example, enthusiastically endorsed both Lichtenthal's roial' and the roial' manufactured by Johann Friedrich Schreder. He valued the rich, singing tone of the Schreder roial' ${ }^{3}$ Following Liszt's endorsement of the Lichtenthal grand, the firm experienced a record increase in domestic sales. The Journal de Saint-Pétersbourg, 18/30 August 1842, recorded the pianist's endorsement of the Lichtenthal roial':

"M. Liszt, qui avait ouvert la séance avec un concerto de Hummel dont il s'était montré le plus digne interprète, l'a terminée par un concerto de Beethoven [...] le virtuose s'est surpassé lui-même.

[...] On faisait venir à grands frais des pianos de l'étranger, tandis qu'on avait là, près de soi, l'un des meilleurs facteurs de l'Europe [...] A tous ses concerts, le grand pianiste [Liszt] fait placer l'un des instruments de Lichtenthal à côté d'un piano [importé]. On les entend alternativement, on les compare, et bien souvent c'est celui de Lichtenthal qui l'emporte. Depuis cet instant, les ateliers de ce facteur [Lichtenthal] sont en grande activité, c'est à qui pourra se procurer un piano de sa fabrique." ${ }^{4}$

Indeed, the piano conquered Russian society in the nineteenth century. The successful marketing of the roial', or concert grand, and the pianino, the smaller, upright piano, marked the triumph of the domestic-manufactured instrument in the concert halls and in the drawing rooms of the gentry and raznochintsy. Both Alexander I and his successor, Nicholas I, supported amateur societies, artisans, artists, and composers. Court support served a political function. Imperial patronage enabled Alexander to maintain a cultural profile that was essentially European. It reinforced his prevailing view of a westernized Russia that rightfully belonged to the established pan-European alliance of Prussia, Austria, Great Britain, and France.

Public interest in the piano and increased participation in music afforded a ready-made consumer market for the burgeoning music industry in Russia. Evidence from the Russian music journal, Nuvellist, indicates that amateur societies, in particular, helped create a thriving domestic market not only in the

3. F. A. Brokgauz, I. A. Efron, Entsiklopedicheskii slovar, ed. I. E. Andreevskii, T, 3 (St. Petersburg, 1891): 353.

4. Journal de Saint-Pétersbourg (18/30 août 1842): 1930. "Liszt, who began his performance with a concerto of Hummel and concluded with a concerto of Beethoven [...] surpassed himself. [...] Foreign [manufactured] pianos were brought here at great expense, even though one of the best manufacturers in Europe is close by. [...] At all concerts, the great pianist [Liszt] placed one of Lichtenthal's instruments next to the [imported] stage piano. We heard each in turn, compared them, and, generally speaking, Lichtenthal's carried the day. Since then, [Lichtenthal's] workshops have been quite busy, filling orders for the large number of people who want to purchase a piano from his manufacture." 
capitals of Moscow and St. Petersburg, but also in the cities of Kazan and Kiev. ${ }^{5}$ From 1820 to 1850 the Russian piano industry benefited directly from the sales of domestic instruments. Piano manufacturers furthered economic and technological development through the manufacturing process. The Romanov family, in turn, lent support to the piano industry.

European artisans founded more than a dozen piano workshops in Moscow and St. Petersburg between 1810 and 1850 . Their arrival in 1810 coincided with the beginnings of the Industrial Revolution in Russia. Alexander I and Nicholas I, who encouraged the settlement of European artisans and entrepreneurs during the first half of the nineteenth century, extended patronage in the form of state loans, monopoly rights, and trade privileges to small industrial workshops that included those of piano artisans. This patronage enabled European artisans to expand their base of production in Russia. For Russian artisans, unlike their European counterparts, were not organized into the guilds that provided much of the political and economic base for the artisans of western and central Europe. The recruitment of foreign specialists in music had begun in Russia in the mid-eighteenth century and continued through Nicholas I's reign.

The achievements of piano manufacturers in St. Petersburg paralleled Alexander's attempts to transform the capital from a center of officialdom into one of commerce and industry. The gradual transformation of the capital during Alexander's reign coincided with the increased patronage of artisans and piano manufacturers. Although the recruitment of foreign specialists in Russia reached its peak in the mid-eighteenth century during Elizabeth's reign, the practice continued in the late eighteenth and early nineteenth centuries under Catherine II, Paul I, and Alexander I.

Encouraged by Alexander's advocacy of domestic trade and manufacturing, piano builders from western Europe first moved to establish factories in Russia in 1810. The tsar protected domestic manufacturers against foreign competition in two ways. First, he levied high import taxes for European-manufactured instruments. Second, he enacted restrictive tariff laws in 1822 and 1824 that benefited domestic manufacturers. Nicholas enacted additional restrictive tariff laws in 1841 .

Along with the manufacturing firms, technological and trade journals proliferated. These journals focused on recent developments in manufacturing processes in England, Germany, Scotland, and Austria. Both Alexander and Nicholas sought to incorporate scientific and technological innovations into Russian industry between 1810 and 1850 . Most notably, two technology and trade journals, Zhurnal manufaktur i torgovli and Listok promyshlennosti, remesl, iskusstv i fabrik, circulated widely in Moscow and St. Petersburg in the 1820s and 1830s. ${ }^{6}$

5. Literaturnoe pribavlenie $k$ Nuvellistu, 1(1844): 1-3.

6. Zhurnal manufaktur i torgovli, 1 (1825): 133-145; Listok promyshlennosti, remesl, iskusstv $i$ fabrik, 1-2 (1838): 24-26. 
Noveishie, or modern, manufacturing processes in the piano industry largely drew upon technology developed in Great Britain in the late eighteenth and early nineteenth centuries. European artisans, for the most part, implemented the existing technology in Russia and applied it to the manufacture of pianos. Imperial patronage of builders and manufacturing entrepreneurs helped create a domestic market for keyboard instruments in provincial and rural areas. Further, the achievements of piano manufacturers in St. Petersburg during the early part of the nineteenth century coincided with the transformation of the capital into a leading center of commerce and industry.

Manufacturing formerly signified primarily production by means of ruchnaia rabota, or manual work. Beginning in the 1830 s manufacturing signified industrial production by means of machines. The change in the meaning of the word indicates the beginnings of an industrial revolution in Russia. According to the manufacturing journal, Listok promyshlennosti, remesl, iskusstv i fabrik, 1838, machines now replaced the manual work in the masterskaia, or workshop. ${ }^{8}$ The journal further states that having the work done by machines or an automatic system had been practiced in England for the last thirty years.

The population of Russia increased by more than $80 \%$ between 1811 and 1863 and much of the growth took place in urban cultural centers. Moscow and St. Petersburg, in particular, attracted foreign industrialists, bankers, and merchants from Great Britain and the German-speaking states. ${ }^{9}$ The gentry and raznochintsy provided a thriving market for domestic manufacturers. They contributed to the social cachet and financial success of the domestic piano. The piano industry expanded the trade opportunities with western Europe and within the Russian empire between 1810 and 1855. It encouraged the development of technology and trade in both rural and urban areas during a period of intense industrialization under Nicholas I. Despite the fragmentation of the consumer market in outlying regions of the empire, the demand for domestic pianos increased between 1810 and 1850 . Russian piano manufacturers routinely shipped their instruments to the estates of the gentry and the homes of the raznochintsy located more than 500 kilometers from the capitals of Moscow and St. Petersburg. The domestic piano enabled artisans and entrepreneurs to reinforce a fashionable cultural profile that was essentially European.

Between 1800 and 1820 eight European artisans formed the nucleus of the Russian piano industry. These included the St. Petersburg firms of Theodore Diederichs [in Russian, Feodor Feodorovich Diderikhs'] (founded in 1810); Andreas Kestner (founded in 1803); Aleksei Nechaev (founded in 1800); A. A. Faverev (founded in 1800); Johann Zimmerman [Iu. G. Tsimmerman]

7. William L. Blackwell, The beginnings of Russian industrialization (Princeton: Princeton University Press, 1968): 96.

8. Listok promyshlennosti, remesl, iskusstv i fabrik, 1-2 (1838): 33.

9. William L. Blackwell, ed., Russian economic development from Peter the Great to Stalin (New York, 1974): xxvi. 
(founded in 1806); Johann Friedrich Schreder (or Schröder) [Iogann Fridrikh Shreder] (founded in 1818); Ivan Karlovich (founded in 1818); and Johann August Tischner [I. A. Tishner] (founded in 1800). ${ }^{10}$ All ceased production in 1917.

As early as 1801, when the earliest piano workshops were established in St. Petersburg, Sankt-Peterburgskie vedomosti published a brief notice concerning the invention of a new keyboard in Vienna. ${ }^{11}$ The instrument was capable of conveying the tone quality of the organ, harmonica, flute, piano, and more than 100 woodwind and string instruments. The Italian-born opera composer, Antonio Salieri (1750-1825), who in 1774 succeeded Gassmann as court composer and conductor of the Italian opera in Vienna, proclaimed the instrument absolutely one of its kind. Sankt-Peterburgskie vedomosti, 22 November 1801, announced that I. G. Strassner, a collector of mechanical instruments, offered for sale his large collection of mechanical instruments and a fortep 'iano with musical spirit, at a price to be negotiated. ${ }^{12}$ Another Moscow collector, Aleksei Mitropolit, advertised for sale a fortep iano with two sustaining pedals at a reasonable price. ${ }^{13}$

There was a thriving market for Russian-manufactured pianos in the early decades of the nineteenth century. In the early 1820 s pianos were advertised for sale in Moscow and St. Petersburg. Moskovskie vedomosti, 19 March 1823, offered for sale a six-octave fortep iano built in St. Petersburg by an unidentified artisan. ${ }^{14}$ In 1832 an advertisement called attention to the availability of a sixoctave fortep 'iano built by the Moscow-based artisan Gerasim Ebermann. ${ }^{15}$

One piano builder, a Mr. Thoresen, advertised regularly in the Journal de SaintPétersbourg in the 1840s. Thoresen, however, directed his efforts toward the musical amateurs who belonged to the numerous court-sponsored musical societies. He provided brief testimonials from Adolf von Henselt (1814-1889), whom Nicholas I had recently appointed court pianist in 1838. Together Thoresen and Henselt "recommended to music lovers a piano of a new genre, with a very simple and durable mechanism, with a very good sound, able to hold its tune for quite a long time, and very easy to play." The advertisement closed with the statement, "The undersigned give their entire approval to $\mathrm{Mr}$. Thoresen's advertisement. A[dolph von] Henselt, A[nton] Herke [Gerke]":

\footnotetext{
“Annonces. Pianos. Le Soussigné a l'honneur de recommander aux amateurs de musique ses pianos d'un nouveau genre, d'un mécanisme simple et durable, qui ont un très beau son, tiennent l'accord très longtemps, et qui sont très faciles à jouer.
}

10. R. V. Chugunnikov, Katalog fortep iannykh predpriiatii 1492 g.-1932 g. (Belgorod, 1972): $12-30$.

11. Sankt-Peterburgskie vedomosti(16 July 1801): 2121.

12. Ibid. (22 November 1801): 3210.

13. Moskovskie vedomosti (20 July 1801): 1331.

14. Ibid. (19 March 1823): 718.

15. Ibid. (30 March 1832): 1197. 
Pour preuve, il a le droit de présenter l'attestation suivante de M. Henselt, pianiste de la Cour, et de M. Gerke, artistes bien connus.

'Les soussignés donnent leur entière approbation à l'annonce du sieur Thoresen.'

A. Henselt

A. Gerke.

[...] Thoresen, facteur de pianos."16

Through Henselt's endorsement the piano became associated with upward mobility and the culture of the court. Henselt introduced a new, more robust performance style in Russia. He also expanded opportunities in music education for women. In 1863, he was appointed inspector general of the Imperial Female Institutes. These included the Smol'nyi Institute, the Mariinskii Institute, and the Catherine Institute. Henselt widely disseminated the works of European masters, most notably, those of Chopin, Beethoven, and Carl Maria von Weber, to students of the institutes and to the members of the court-sponsored amateur societies.

Theodore Diederichs (d. 1846) was one of the earliest successful piano manufacturers in Russia. Diederichs was formerly employed as an artisan with the French clavichord firm of Fèvre. He founded the oldest piano factory in St. Petersburg: in 1810 he opened a piano workshop on Vasil'eveskii Ostrov with only one apprentice. He immediately set out to promote his expensive roial', or grand piano. He advertised the roial' as an instrument with superior tone quality. The Diederichs piano gradually replaced the imported pianos of Broadwood and Pleyel in the drawing rooms of the Russian gentry. By 1812, just two years after the founding of the firm, Diederichs increased the number of skilled artisans, or remeslenniki, from one worker to fifteen. By 1822 he employed thirty artisans and moved to larger quarters on Vasil'evskii Ostrov. ${ }^{17}$ The firm manufactured the pianino, or smaller upright piano, and the concert roial'.

After Diederichs's death in 1846 the ownership of the piano factory remained in the hands of his family. His widow, Ekaterina Andreevna, now the sole support of the couple's nine children, assumed the management and supervision of the factory, a position she held until 1868. Ekaterina Andreevna is referred to in promotional literature for the firm as the soul of the enterprise. In 1868 her eldest son, Robert Feodorovich (d. 1893), assumed all managerial responsibilities and in 1870 , he became the owner of the firm.

Robert Feodorovich concentrated his efforts on the technological improvements in the construction and design of the concert roial'. He was well rewarded for his efforts. The Diederichs roial' received highest honors at the 1870 St. Petersburg Universal Exhibition and at the 1896 All Russian Exhibit in Nizhny Novgorod. In 1896 the firm received the royal coat of arms as chief purveyor to the tsar. In 1878

16. Journal de Saint-Pétersbourg (11/25 décembre 1846): 524. Advertisement for the Thoresen Piano Factory.

17. Kratkii istoricheskii ocherk stareishei fortepiannoi fabriki Rossii "Brat'ia R. i A. Diderikhs"," osnovannoi v 1810 g. (St. Petersburg: Tip. V. Avidon, 1911): 1. 
Robert Feodorovich's brother, Andrei Feodorovich (d. 1904), joined the firm. After Robert's death in 1893, Andrei became the owner of the Diederichs factory. In 1896, fueled by the firm's success at the All Russian Exhibit, Andrei expanded the manufacturing arm to meet the increased demand for domestic pianos. In 1900 he attended the World Exhibition in Paris where he was decorated as an Officer of Public Instruction. Following Andrei's death in 1904, the factory ownership transferred to his widow, Anna Feodorovna, and remained in her hands until 1917. For more than a century Diederichs remained a highly respected family-owned manufacturing firm in St. Petersburg.

Beginning in the $1830 \mathrm{~s}$, Diederichs, Schreder, and other builders, took advantage of the changing technology in piano manufacturing in order to meet the needs of visiting professional musicians who performed in Russia. In particular, these musicians included (in addition to Liszt and Thalberg), the already mentioned Alexander Dreyschock, Clara Schumann, and Madame Pleyel. ${ }^{18}$

The Journal de Saint-Pétersbourg, 31 August/12 September 1839, describes the technological advances of the Russian-manufactured piano. ${ }^{19}$ Diederichs sought to produce a roial' that featured a powerful sound and expressive tone quality. The firm focused on reverberation, resonance, and prolongation of the tone. Liszt and Thalberg demanded an instrument that produced rapid repetition of single notes. Clara Schumann and Marie Pleyel wanted increased expressivity and a powerful sound. The demands of the romantic pianist presented an enormous challenge to Russian manufacturers, for technical advances had remained sporadic in the $1820 \mathrm{~s}$ and for much of the $1830 \mathrm{~s}$. Yet more problems remained for the smaller firms that lacked the technical expertise that served as a mainstay for Diederichs and Schreder. The firms of Andreas Kestner, Aleksei Nechaev, and A. A. Faverev were unable to produce an instrument with a powerful sound. Further, they did not solve the problems of reverberation and prolongation of the tone. These firms did not survive. Thus the evidence illustrates that the technological advancements of the larger firms, namely, Diederichs and Schreder, did not necessarily filter down to the smaller firms.

The European artisan Johann Friedrich Schreder established a piano workshop in St. Petersburg in 1818. The factory ceased production in 1917. Schreder introduced new ways of creating a more powerful sound in the roial', or grand piano. The Schreder roial' was the first Russian-manufactured piano to incorporate a cast-iron sound board within an ornately carved wooden frame..$^{20}$ By 1860 the firm employed 300 remeslenniki, or skilled artisans. ${ }^{21}$ In 1871 the Schreder factory merged with the firms of M. A. Bietepage [Bitepazh] and P. L. Petersen. Johann Schreder's son, Karl I. Schreder (d. 1889), introduced the American system of

18. Journal de Saint-Pétersbourg (10/22 décembre 1838): 596.

19. Ibid. (31 août/12 septembre 1839): 106.

20. N. Bondarenko, Fortepi'ano $i$ ego predshestvenniki (Moscow: Gosudarstvennyi tsentral'nyi muzei muzykal' noi kul'tury im. M. I. Glinki, 1980): 17.

21. F. A. Brokgauz, I. A. Efron, op. cit., T. 39 (St. Petersburg, 1903): 858. 
cross-stringing to the Russian-manufactured roial'. Between 1818 and 1900 Schreder manufactured more than 25,000 pianos in Russia. The market for domestic pianos increased steadily throughout the nineteenth century. Schreder's roial', with its rich, singing tone and its pleasant and light touch found favor with Liszt, Charles d'Albert (1864-1932), Anton Rubinstein, and Rubinstein's student, Josef Casimir Hoffman (1876-1957). Russian manufacturers adapted the technology to suit the needs of visiting professional musicians. Developments in piano construction concerning resonance and reverberation took place during the $1840 \mathrm{~s}$. The increase in the number of skilled workers and the production of instruments illustrate the extent to which Schreder, Diederichs, and other piano firms contributed to the market for consumer goods during the $1840 \mathrm{~s}$ and $1850 \mathrm{~s}$.

In the aftermath of the European revolutions and national uprisings of 1848 and 1849 in France, Italy, Germany, and the Austrian Empire, piano builders settled in Russia. Between 1830 and 1850 , they founded more than a dozen factories, among them the firms of Hermann Lichtenthal (founded in 1840), Jakob Davidovich Becker (founded in 1841), G. Lüdecke [in Russian, Ludeke] (founded in 1835), G. Schultz [Shul'ts] (founded in 1835), K. M. Ilver (founded in 1842), Kelberer (founded in 1849), Zimmerling (founded in 1849), and Vitmak (founded in 1849).22 These firms ceased production in 1917.

The market for pianos remained high and the earning power of the professional musician in Russia was substantial. Modern technology and censorship of music played a significant role in the internal affairs of the state from 1833 , with the emergence of Nicholas's russification policies, until his death in 1855 . The founding of the Becker and Lichtenthal factories coincided with Nicholas's modernization of Russian industry. Restrictive import tariffs enacted in 1841 added to the cost of European-manufactured pianos and provided Becker and Lichtenthal with an almost unlimited market for domestic instruments. Further, low wages and restrictive tariffs, in effect, created a monopoly for Russian-manufactured pianos. When the prices of European-manufactured pianos increased substantially in the 1840s, Becker and Lichtenthal advertised the merits of their high-quality, low-cost pianos to the general public.

Lichtenthal's small imperial cabinet sold for 600 rubles, less than half the price of a comparable imported piano. The Lichtenthal roial', an eight-octave imperial rosewood grand, sold for 800 rubles. By way of comparison, the imported pianos of Broadwood and Pleyel, for example, averaged from 3,000 to 5,000 rubles. ${ }^{23}$ The music publisher Matvei M. Bernard praised the domestic manufacturers in a series of essays in the Nuvellist, April 1849.24 In an essay entitled "De la fabrication des pianos" that appeared in the Journal de Saint-Pétersbourg, 24 May/5 June 1841, Lichtenthal revealed his patented system for the repair of soundboards of unspecified European-manufactured instruments. "La plupart sont bientôt comme

22. R. V. Chugunnikov, op. cit.: 15-16, 18-19.

23. Journal de Saint-Pétersbourg (24 mai/5 juin 1841): 1161 .

24. Literaturnoe pribavlenie $k$ Nuvellistu, 4 (Apri1 1849): 28-29. 
frappés d'étisie, et l'on a beau les habiller à neuf, changer les marteaux, renouveler les cordes, etc., rien ne peut dissimuler le mal dont ils sont atteints."25

Lichtenthal's patented system for repair of distressed pianos involved an arrangement of the strings on equidistant bridges. Through the use of this system, Lichtenthal sought to create a more even distribution of the weight of the strings above the sound board. His eight-octave piano maintained its pitch due to the insertion of a doska, or metal plate, located inside the wooden frame. All Lichtenthal instruments had a range of eight octaves and a metal sound board. Lichtenthal patented his string distribution system in London, Paris, and St. Petersburg.

In the years following the European revolutions of 1848 , censorship imposed additional restrictions on published music; it restricted the dissemination of printed music because it feared the possible concealment of coded material in musical notation. Yet the Romanov family supported the music industry. The Romanovs established conservatories and educational institutes in all parts of the empire and the family assumed additional financial responsibility for Russian composers. Elena Pavlovna offered 1,000 rubles to the composer and critic Aleksandr Serov (1820-1871) during a period of financial hardship following the successful premiere of his first opera, Judith, at the Mariinskii Theater in $1861 .^{26}$

Although prices for the roial' varied substantially by 1870 , the cost was still prohibitive for most of the Russian population. The average skilled worker in the piano factory earned approximately one ruble per day. One skilled worker would have toiled for more than two years to earn the sum of 800 rubles for the Lichtenthal eight-octave rosewood roial'. By way of comparison, this sum equaled approximately half of the monthly stipend Nadezhda von Meck offered the composer Piotr Tchaikovsky (1,500 rubles per month in 1877).

Additional piano manufacturing firms were established in St. Petersburg in the 1850s and 1860s. Theodore Michael Miulbach (or Mülbach) [Feodor Mikhailovich Miul'bakh] founded a piano factory in 1856 . By 1866 the factory produced five hundred instruments. ${ }^{27}$ In a lengthy essay in the Russian music journal Muzykal'nyi svet, Miulbach advertised his kontsertnyi roial', a seven-octave rosewood concert grand that featured English action, for 575 rubles. ${ }^{28}$ The St. Petersburg firm of M. Petersen specialized in the manufacture of the roial'. Petersen advertised in the Journal de Saint-Pétersbourg, 24 June/6 July 1847, that he had recently manufactured a wide array of perfectly crafted grand pianos that

25. Journal de Saint-Pétersbourg (24 mai/5 juin 1841): 1161. "Soon, most [of the imported pianos] are likely stricken with étisie, or fatigue, and it is of no use to dress them in new clothes, change the hammers, nor renew the piano strings. Nothing can alleviate the disease from which they are suffering."

26. Dmitrii Aleksandrovich Obolenskii, Moi vospominaniia o velikoi kniagine Elene Pavlovne (St. Petersburg: Tip. "Nadezhda," 1909): 70.

27. F. A. Brokgauz, I. A. Efron, op. cit., T. 20 (St. Petersburg, 1897): 362.

28. Muzykal'nyi svet (March 1870): 11. 
featured a beautiful sound. Petersen, like Lichtenthal, shipped his roial' to "all the regions of the empire" at a "most moderate cost":

\begin{abstract}
"Annonces. L. Peterson. Facteur de Pianos. Perspective de Nevsky [...] a l'honneur de prévenir, que l'on trouve toujours dans ses ateliers un grand assortiment de Pianos et de Royals, parfaitement soignés sous le rapport du travail, et ayant un très beau son ; il a également des instruments qu'il donne en location ; les envois pour tous les gouvernements de 1'Empire se font aux prix les plus modérés." 29
\end{abstract}

The Miulbach concert grand, at the price of 575 rubles, was primarily affordable for the nobility and the merchant elite. By way of comparison, the annual tuition for the St. Petersburg Conservatory in 1867 was 100 rubles. In 1861 the per capita income for Russia was 71 rubles, compared to 150 rubles for France and 450 rubles for the United States. ${ }^{30}$ In 1867 the Grand Duchess Elena Pavlovna allotted 5,500 rubles for faculty salaries at the St. Petersburg Conservatory. Due to extreme fluctuations in the value of the ruble after the Crimean War, the currency depreciated considerably during the $1860 \mathrm{~s}$. Yet the piano industry thrived and interest in music remained high. The roial' remained well within the financial reach of successful Russian artists as well. Official records indicate that Anton Rubinstein earned the enormous sum of 19,516 rubles from the proceeds of one public concert in St. Petersburg in 1892.31

Jakob Davidovich Becker, a German-born artisan, founded a piano factory in St. Petersburg in 1841. Becker's instruments featured a resonant sound, flexible keyboard action, and solid construction. Becker was the first to incorporate European and American technology into piano manufacture in Russia. He duplicated Erard's double escapement and adapted the American system of crossstringing. ${ }^{32}$ Becker confirmed his technological breakthrough in an essay that appeared in the Journal de Saint-Pétersbourg, 7/19 November 1844:

"Annonces. Jacques Becker. Facteur de pianos. Maison de la Comtesse Tolstoi à St.-Pétersbourg.

Occupé depuis longtemps, tant à l'étranger qu'ici, à travailler au perfectionnement des Pianos, des efforts continus firent naître en moi diverses idées, qui m'ont enfin conduit à un résultat heureux, et je réussis à construire une espèce tout à fait nouvelle de Pianos à queue, pour laquelle j'obtins, en 1839, un privilège de dix ans de $S$. M. Le Roi de Bavière.

29. Journal de Saint-Pétersbourg (24 juin/6 juillet 1847): 1132. Both spellings "Petersen" and "Peterson" are employed in advertisements and in discussions concerning piano manufacturers.

30. Peter Gatrell, The Tsarist economy, 1850-1917(New York: St. Martin's Press, 1986): 32.

31. Journal de Saint-Pétersbourg (11/23 janvier 1892): 3.

32. N. Bondarenko, op. cit.: 17. 
Mes expériences m'avaient coûté des sacrifices pécuniaires fort onéreux; bien que parfaitement apprécié dans mon pays, je résolus de me transporter à St. Pétersbourg, espérant y trouver une sphère d'activité plus vaste $[\ldots]$ "33

Several leading pianists endorsed the Becker roial'. The Polish-born pianist, Antoni Kątski, who studied with John Field in Moscow from 1829 until 1830, praised the instrument's elegant design, powerful sound, and beautiful singing tone. The Becker piano was mentioned in a review of one of Kątski's concerts in St. Petersburg's Philharmonic Hall in 1855. According to the reviewer, the Becker roial' enabled the pianist to interpret richly all the colors and nuances of the music, “à commencer du pianissimo le plus suave, le plus argentin, jusqu'aux limites extrêmes de la sonorité pianotique." ${ }^{34}$ The tone quality of Becker's roial' surpassed that of its rival manufacturer, Lichtenthal. ${ }^{35}$ Becker's roial' and smaller pianino both featured a resonant sound, flexible keyboard action, and solid construction. The instrument retained its pitch throughout an entire performance.

In 1861 Jakob Davidovich's brother, Franz, assumed the management of the Becker factory in St. Petersburg. In 1871 the Becker family sold the firm. M. A. Bietepage and P. L. Petersen became the co-owners of the Becker factory. The firm relocated to larger quarters in St. Petersburg. The new site housed castiron and copper-casting departments, and metal workshops. The enlarged factory included additional separate departments for remeslenniki, or skilled craftsmen, and metalworkers. From 1841 until 1891 the Becker factory produced approximately 11,400 roiali. Although opportunities for skilled workers increased, however, wages remained low and the hours were long. In 1891 the Becker factory employed 300 remeslenniki. In 1899 a fire destroyed the factory and the ownership of the firm transferred entirely to M. A. Bietepage. In 1903, two years before the 1905 Revolution, Bietepage merged with the firm of Ivan Karlovich Schreder. In 1917, the substantial assets of the Becker factory were nationalized and the manufactory was transformed into the Red October piano factory.

Domestic pianos were well received in areas remote from the urban centers. Lichtenthal added four rubles per thousand versts (1 verst: 3,500 feet, or 1.06 kilometers) for shipping outside Moscow and St. Petersburg. For distances beyond 2,000 versts, the purchaser was expected to pay an extra ten rubles for a metal shipping box to protect the instrument during delivery. ${ }^{36}$ Further, Lichtenthal

33. Jounal de Saint-Pétersbourg (7/19 novembre 1844): 3306. "For a long time, both here and abroad, I have dedicated myself to perfecting the piano, and my continual efforts have finally led me to successful results. I have succeeded in constructing an altogether new type of grand piano. In 1839 I obtained a ten-year privilege for its manufacturing from His Majesty the King of Bavaria. My experiments have resulted in heavy financial sacrifice. Although well respected in my country, I was determined to travel to St. Petersburg, where I hoped to find a much wider sphere of activity."

34. "[...] from the softest and most silver-toned pianissimo to the extreme limits of the piano's sonority," Ibid. (17/29 novembre 1855): 3633.

35. Ibid. (7/19 novembre 1844): 3306.

36. Muzykal'nyi svet(March 1870): 11. 
guaranteed the repair or replacement of all pianos for a period of ten years. Evidence from the Russian music journal, Muzykal'nyi svet, March 1870, indicates that Lichtenthal shipped a considerable number of instruments to large estates remote from the capital. The market for domestic instruments extended well beyond the urban areas, as Russian builders continued to receive loans, bonuses, and direct subsidies from the state. Transportation of raw materials, in particular, received subsidies in the 1860 s and 1870 s.

The manufacture and shipment of domestic pianos beyond the urban centers coincided with the era of Russian colonialism that took place during the reign of Alexander II. Evidence from rare Russian journals and gazettes illustrates the extent to which the broader Central Asian region provided new markets for piano manufacturers. Muzykal'nyi svet, March 1870, notes that by 1870 Russian pianos from the St. Petersburg factories of Lichtenthal, Becker, Schreder, and Miulbach were routinely shipped to all parts of the empire. ${ }^{37}$ Financial records in the journal Batum, 20 November/2 December 1888, indicate that profits derived from trade in the annexed territories brought in substantial revenue for the state. The income derived from the taxation of immovable property and from the interest on state loans in the Central Asian region amounted to 483,000 metal rubles in 1888.38 The industrialization of the region provided new markets for domestic manufactured goods, including pianos. The music store Vostochnaia lira advertised immediate shipment of the Becker, Schreder, and Miulbach roial' in the gazette Kazanskie gubernskie vedomosti. ${ }^{39}$

Music education and the performing arts benefited from the economic advantages derived from trade with the newly annexed regions. As Russia expanded further into the Central Asian region and to the east, the Romanov family continued its support of educational institutes associated with the Imperial Russian Musical Society. Moskovskie vedomosti, 24 October 1888, reported that music schools in Kharkov and Tiflis (Tbilisi) received yearly stipends, 5,000 rubles each, a generous sum. By way of comparison, the established conservatories in Moscow and St. Petersburg received 15,000 and 20,000 rubles annually.

State theaters, in particular, those reserved for staged operatic productions, also received state support. For example, in 1888 the Romanov family donated 42,195 rubles to the state theater in Tiflis. By way of comparison, the remaining state theaters in the western gubernii, or provinces of 300,000 inhabitants, received approximately 18,000 rubles. ${ }^{40}$ Russian operas with eastern themes flourished. According to Kazanskie gubernskie vedomosti, 6 October-13 December 1888, the 1888-1889 season at the Kazan State Theater featured Glinka's Ruslan and Liudmila (1837-1842), Anton Rubinstein's The Demon (1871), and Cesar Cui's

37. Ibid:: 1 .

38. Batum. Telegrammy chastnye ob"iavlenia severnogo telegrafnogo agenstva (20 November/2 December, 1888): 2 .

39. Kazanskie gubernskie vedomosti $(6$ October 1888): 4 .

40. Moskovskie vedomosti (24 October 1888): 4. 
Prisoner of the Caucasus (1857-1858). ${ }^{41}$ The support of music schools and theaters in Kharkov and Tiflis implemented the cultural shift that occurred in imperial Russia in the 1880 s as German workers emigrated to Russia in order to work in the new industrial centers of Ukraine (formerly Russian Poland) and Georgia (annexed by Russia in 1801).

In exchange for land, self-government, and religious freedom, German colonists settled in Russia in 1762 at the invitation of Catherine II. German emigration continued through the nineteenth century. In the 1880 s the industrial growth in Ukraine and southern Russia led to an influx of industrial workers along the lower Volga. Factory workers and city dwellers aspired to the cultural trappings of the aristocracy. They bought inexpensive domestic pianos, joined amateur choruses, attended staged productions, and bought low-cost sheet music. In turn, publishers paid generous royalties to composers who supplied simple pieces for the amateur market. These pieces regularly appeared in monthly musical supplements to subscription journals. For the most part, these pieces imitated the sets of dances and instrumental variations associated with eighteenth-century classicism.

Alexander II carried on active trade and diplomacy with the Caucasus, Central Asia, and the Far East. His military expeditions into Central Asia took place from 1865 until 1878. In 1878, under a treaty with Turkey, Russia annexed Batum, Kars in Transcaucasia, and the southern part of Bessarabia. The region attracted the attention of Russian composers. Both Mily Balakirev (1837-1910) and Nikolai Rimsky-Korsakov (1844-1908) spent extended periods of time in the Caucasus. In 1881 Rimsky-Korsakov, journeyed to the Caucasus. In 1886 he visited the cities of Batum and Tiflis. In 1880 Central Asia served as a theme for the commemoration of the twenty-fifth anniversary of Alexander's rule. In 1888 Rimsky-Korsakov completed his oriental fantasy, Sheherazade.

The wave of immigration spurred by the revolutions of 1848 uprooted many skilled artisans from the German-speaking states. A number of these skilled workers sought employment in the piano manufacturing industry outside Moscow and St. Petersburg. Evidence on the hours and wages of the skilled worker was culled from a financial manifest prepared by the A. Strobl factory in Kiev in 1891.42 The workday for the Strobl factory began at 6:00 a.m., with a fifteen-minute break for breakfast at 8:00 a.m. Workers were not permitted to leave the factory during the break period. Lunch hour was from noon until 1:00 p.m. Workers resumed their duties from 1:00 p.m. until 7:00 p.m., without a break. On Saturdays the workday ended at 6:00 p.m. Workers earned between 1 ruble and 1 ruble 15 kopecks per day, payable after completion of the assigned task. The average worker worked for two years and two months in order to meet the purchase price of the roial', which sold for approximately 800 rubles. Despite the low wages, however, the average annual

41. Kazanskie gubernskie vedomosti (6 October 1888): 4; (11 October 1888): 4; (13 October 1888): 4; (20 October 1888): 3; (8 December 1888): 3; (13 December 1888): 3 .

42. Fortep iannaia fabrika A. StrobI' (Kiev: G. L. Fontskevicha, 1891), "Kiev, 23 November 1891 , permission from the censor," fol. 1. 
wage for the skilled factory worker in 1891 was approximately five times greater than Russia's per capita income in 1861 .

Regulations in the Strobl factory were strictly enforced. Workers were admonished to be economical with costly timber, in particular, they should not hurl rare woods into the stove as firewood. Conversations with co-workers were forbidden, except for those relating to business. Unpleasant and intoxicated behavior and the drinking of vodka and other spirits was prohibited. The smoking of tobacco was permitted. Apprentices absent from work for more than three days without sufficient cause should submit their resignation to the factory manager. Apprentices were not allowed the right to appeal to the law courts concerning the payment of wages or dismissal from the job.

Similar wages were paid to the skilled workers in the Becker piano factory in St. Petersburg. The daily production of the 300 skilled workers yielded two or three grand pianos and an unspecified number of smaller upright pianos. ${ }^{43}$ The average wage amounted to one ruble per day for each of the 300 skilled workers, or 300 rubles per day. A conservative estimate of the wages for the skilled workers who worked for the Becker factory amounted to approximately 93,600 rubles per year. The average wage of one ruble per day was a fair wage, amounting to approximately 312 rubles per year (based on a six-day week and fifty-two weeks a year). This was greater than the salary of an eighteenth-century actuary, archivist, or registrar employed in an administrative post in St. Petersburg. In the mideighteenth century an actuary or registrar earned 200 rubles yearly, an archivist earned 180 rubles in annual salary. ${ }^{44}$ The annual sales of pianos from the Becker factory represented a substantial sum. The yearly income takes into account the daily production of two roiali at 800 rubles each ( 1,600 rubles) and 2 small cabinets at 600 rubles each (1,200 rubles). The annual sales figures for the Becker factory amounted to approximately 873,600 rubles. By way of comparison, the expenditures for the court of Catherine II rose from $1,750,00$ rubles in 1762 to $6,800,000$ rubles in $1794 .{ }^{45}$

The nineteenth-century piano as a symbol of the noveishii, or modern style, figured prominently in an article by the American composer and pianist, Louis Moreau Gottschalk (1829-1869). His article, "Music, the piano, and pianists," appeared in Russian translation in Muzykal'nyi svet, January 1861. Gottschalk wrote that the piano, once one of the least interesting members of the great family of instruments, had now become one of the most fertile, most varied, and most popular instruments of all. ${ }^{46}$ He attributed the heightened interest in the piano to both composer and entrepreneur. He cited recent technical improvements on the

43. F. A. Brokgauz, I. A. Efron, op. cit., T. 3 (St. Petersburg, 1891): 353.

44. Arcadius Kahan, The plow, the hammer, and the knout: An economic history of eighteenthcentury Russia, with the editorial assistance of Richard Hellie (Chicago and London: The University of Chicago Press, 1982): 360.

45. Ibid: 337.

46. Muzykal nyi svet (January 1861): 3. 
instrument and he referred specifically to the music itself, which he called the beautiful compositions of the modern virtuosi. Gottschalk wrote that the rich sounds of the modern piano created a full range of new musical effects that included fingering techniques and variation techniques that overwhelmed the listener. Gottschalk was one of the first to apply the term, noveishii, to a new performance style. He detailed his views on the modern virtuoso in a subsequent article that appeared in Muzykal'nyi svet, February 1861.47

In 1864 the Moscow firm of A. Kalene introduced a new keyboard instrument that was tuned to a different temperament. In keeping with the spirit of Russian national music, Kalene attempted to recreate the modes featured in the sounds of Russian village songs. ${ }^{48}$ He built the instrument to the specifications of the writer, philosopher, critic, and composer Prince Vladimir Feodorovich Odoevsky (18041869). Kalene's enharmonic clavecin reproduced the modal sound of narodnye, or national, songs. The instrument included a supplementary keyboard that exhibited a different tuning from the equal temperament of the traditional roial and pianino.

Odoevsky, an amateur musician, published the works of Aleksandr Pushkin in his literary almanac Mnemozina (1823-1825). The almanac ceased publication after the Decembrist revolt in 1825 . Odoevsky wrote about the history and paleography of Russian church music. In 1859, with the support of the Grand Duchess Elena Pavlovna, he helped organize the Imperial Russian Musical Society. As a member of the Moscow Senate in the $1860 \mathrm{~s}$, he supported the creation of a national theater that would appeal to a wide audience that included the raznochintsy, in addition to gentry.

Lichtenthal, Diederichs, Schreder, and other Russian firms increased their production in the second half of the century. By 1855 modern technology became closely linked with the repertoire of the keyboard virtuosi. Liszt, Thalberg, and Anton Rubinstein demanded an expressive, yet powerful instrument, one that projected tonal variety and produced dramatic coloristic effects. The performers sought to establish an emotional connection with the audience through the powerful sound of the roial'. The proliferation of scientific and technological studies that Nicholas encouraged reached fruition in the music industry by mid-century. Manufacturers and performers responded to changing musical aesthetics. In particular, domestic manufacturers capitalized on the increased consumer market for instruments, due, in part, to Nicholas's russification policies that restricted the importation of foreign manufactured goods, including pianos.

Piano manufacturers considered additional technological innovations that would implement the emphasis on subjectivity and aesthetic response. Becker succeeded. Lichtenthal did not. Becker focused on the expressive and interpretive qualities of the roial'. Becker sought to project the expressive nuances, simplicity of form, and beautiful melodies that emerged as hallmarks of a modern keyboard style. Chopin, Glinka, and Tchaikovsky served as worthy representatives of a

47. Ibid. (February 1861): 13.

48. N. Bondarenko, op. cit.: 17. 
modern compositional style that relied upon emotion and meaning rather than dazzling keyboard display. Lichtenthal, on the other hand, sought to recreate the powerful sound of the full orchestra on the keyboard.

Lichtenthal empowered performers, most notably, Liszt, Thalberg, and Anton Rubinstein, whose dazzling technical displays electrified audiences. The Journal de Saint-Pétersbourg, 31 August/12 September 1839, described the new musical aesthetic in the following way: "[...] il n'y a là ni décors, ni action pour fasciner vos yeux ou tromper votre esprit; rien que des sons ! Mais ces sons pénétrants sont empreints d'une poésie vague et indéterminée, et les chants qu'ils expriment sont de pures émanations de l'âme."49 These innovations brought emotion and meaning to the art. Becker responded to the aesthetics of the young Russian school. Balakirev, Rimsky-Korsakov, and Tchaikovsky valued expressivity over virtuosity. The technical displays that dazzled audiences in the 1840 s waned by the 1850 s, as Russian composers sought musical meaning in symbols of nationhood.

In the first half of the nineteenth century, piano manufacturers advanced the technology and contributed to Nicholas's vision of a modern Russian state. Women made significant gains in the music profession and in the related arts. Women composers benefited from the proceeds derived from the sale of Russian editions of keyboard and chamber works. They generated additional income from teaching and public performances. The number of professional women in music did not increase dramatically in Russia until the founding of conservatories in Moscow and St. Petersburg in the 1860 s.

Nicholas's sister-in-law, the Grand Duchess Elena Pavlovna, championed the pianist and composer Anton Rubinstein, and lent her support to the western conservatory tradition. Elena Pavlovna (formerly Princess Helena of Wurtemberg), was the daughter of Prince Paul of Wurtemberg. In 1824 she married the Grand Duke Mikhail Pavlovich (1798-1849), the younger brother of Nicholas I. Elena Pavlovna and her nephew, the Grand Duke Konstantin Nikolaevich (1827-1892), were among Tchaikovsky's imperial benefactors. Elena Pavlovna and Konstantin Nikolaevich were both strong advocates of peasant rights and activists in the movement for the abolition of serfdom.

As a leading patron of the Imperial Russian Musical Society, Elena Pavlovna advocated the founding of music institutes and conservatories. She established music schools, women's hospitals, and vocational and technical schools for gentry women and women from the merchant classes in cities remote from the capital, namely, Kiev, Odessa, Kazan, Warsaw, and Irkutsk. ${ }^{50}$ The founding of charitable and cultural institutions reached its peak during the period of "Great Reforms" in the decade following the Crimean War of 1853-1855. In 1862 the St. Petersburg

49. Journal de Saint-Pétersbourg (31 August/12 September 1839): 106. "There is no scenery or action to fascinate your eyes or to deceive your minds, only sounds! But those penetrating sounds represent an obscure and unidentifiable poetry. The songs they express are pure emanations of the soul."

50. Neskol ko slov na pamiat' o v Boze pochivaiushchei Imperatritse Marii Feodorovne i o vedomstve ee uchrezhdenii (St. Petersburg: Tip. Obshchestvennaia Pol'za, 1885): 19. 
branch of the Russian Musical Society, housed on the premises of Elena Pavlovna's home, the Mikhailovskii Palace, achieved the institutional rank of a High Music School, or Conservatory. Anton Rubinstein served as its first director. The conservatory's enrollment increased from 20 students in 1862 to 547 students in 1892; among the latter, 315 were women. ${ }^{51}$ Three major areas of specialization in performance were represented: piano (262 students), orchestral instruments (150 students), and voice (80 students).

Although we have to be extremely careful in interpreting evidence relating to the Russian economy and the ruble in the nineteenth century, we can draw several conclusions from the available data. First, by 1830 musicians under imperial patronage had largely achieved economic parity with the gentry and with those employed in administrative civil service. Piano manufacturers enjoyed imperial patronage through protection from foreign competition and they created a thriving market for domestic instruments. Whereas in the eighteenth century, pianos were largely imported from Europe, between 1810 and 1830 more than a dozen piano workshops were founded in Russia. By 1880, entrepreneurs had founded more than seventy factories in St. Petersburg, Moscow, Kiev, and Odessa. Second, although the economic gains of musicians and institutions under patronage in the $1820 \mathrm{~s}$ slowed in the $1860 \mathrm{~s}$, due, in part, to the declining value of the ruble in the decade following the Crimean War, piano production increased.

Supported by generous government subsidies for the transportation of raw materials and protected from foreign competition by loans and favorable tariffs, skilled artisans and piano manufacturers flourished in centers of trade and commerce. Patronage of amateur societies and professional musicians and institutions created a lively market for domestic instruments. The availability of single and collected editions of the works of living European and Russian masters further stimulated the music industry. Artisans and entrepreneurs changed St. Petersburg from an administrative center into a center of commerce and industry. The workshops of Diederichs and Schreder increased the production of domestic instruments and provided a high quality, low-cost alternative to the more expensive imports.

Despite the lack of administrative reform and the weakened economy during the tenure of the Grand Duchess Elena Pavlovna, music thrived. The lyricism and preoccupation with technical complexities featured in the keyboard works of Anton Rubinstein evoked the conservatory tradition and served as an appropriate vehicle for the expression of such sentiments. Finally, during a period marked by expansive tsarist autocracy on the one hand, and emerging populist and revolutionary movements on the other, the Romanov family's patronage of music temporarily secured the political, social, and cultural ties between the throne and the raznochintsy. Although most nineteenth-century Russian composers were gentry, the piano artisans were not. Imperial patronage enabled composers, musicians, and 
artisans from all backgrounds to pursue successful careers in music. The conservatories, under the patronage of Elena Pavlovna, upheld high standards of performance and composition in the general European repertoire. In addition to the gentry, they broadened participation to include original talents from merchant and peasant backgrounds.

Baruch College of the City University of New York

Department of Fine and Performing Arts

Box $B 7-235$

1 Bernard Baruch Way

New York, NY 10010

anne_swartz@baruch.cuny.edu 